\title{
Prediction of Success in External Cephalic Version under Tocolysis: Still a Challenge
}

\author{
Predição de Sucesso na Versão Cefálica Externa sob Tocólise: Ainda um \\ Desafio
}

\author{
Carolina VAZ DE MACEDO $\bigotimes^{1,2}$, Nuno CLODE ${ }^{1,2}$, Luís MENDES DA GRAÇA ${ }^{1,2}$ \\ Acta Med Port 2015 Sep-Oct;28(5):554-558
}

ABSTRACT

Introduction: External cephalic version is a procedure of fetal rotation to a cephalic presentation through manoeuvres applied to the maternal abdomen. There are several prognostic factors described in literature for external cephalic version success and prediction scores have been proposed, but their true implication in clinical practice is controversial. We aim to identify possible factors that could contribute to the success of an external cephalic version attempt in our population.

Material and Methods: We retrospectively examined 207 consecutive external cephalic version attempts under tocolysis conducted between January 1997 and July 2012. We consulted the department's database for the following variables: race, age, parity, maternal body mass index, gestational age, estimated fetal weight, breech category, placental location and amniotic fluid index. We performed descriptive and analytical statistics for each variable and binary logistic regression.

Results: External cephalic version was successful in $46.9 \%$ of cases (97/207). None of the included variables was associated with the outcome of external cephalic version attempts after adjustment for confounding factors.

Discussion: We present a success rate similar to what has been previously described in literature. However, in contrast to previous authors, we could not associate any of the analysed variables with success of the external cephalic version attempt. We believe this discrepancy is partly related to the type of statistical analysis performed.

Conclusions: Even though there are numerous prognostic factors identified for the success in external cephalic version, care must be taken when counselling and selecting patients for this procedure. The data obtained suggests that external cephalic version should continue being offered to all eligible patients regardless of prognostic factors for success.

Keywords: Breech Presentation; Pregnancy; Tocolysis; Treatment Outcome; Version, Fetal.

\section{RESUMO}

Introdução: A versão cefálica externa é o procedimento de rotação fetal para uma apresentação cefálica através de manobras sobre o abdómen materno. Encontram-se descritos na literatura vários factores prognósticos para o sucesso da versão cefálica externa e foram propostos scores preditores, mas a sua verdadeira implicação para a prática clínica é controversa. Pretendemos identificar possíveis factores contributivos para o sucesso de uma tentativa de versão cefálica externa na nossa população.

Material e Métodos: Examinámos retrospectivamente 207 tentativas consecutivas de versão cefálica externa sob tocólise conduzidas entre Janeiro de 1997 e Julho de 2012. Consultámos a base de dados do departamento para as seguintes variáveis: raça, idade, paridade, índice de massa corporal, idade gestacional, peso fetal estimado, categoria de apresentação, localização placentária e índice de líquido amniótico. Efectuámos avaliação estatística descritiva e analítica monovariada e regressão binária logística.

Resultados: A versão cefálica externa foi bem-sucedida em $46,9 \%$ dos casos (97/207). Nenhuma das variáveis incluídas se associou com o desfecho da tentativa após ajuste para factores de confundimento.

Discussão: Apresentamos uma taxa de sucesso semelhante ao descrito na literatura. No entanto, ao contrário de estudos anteriores, não associámos nenhuma das variáveis analisadas com o sucesso das tentativas de versão cefálica externa. Acreditamos que esta discrepância poderá ser parcialmente explicada pelo tipo de análise estatística efectuada.

Conclusões: Apesar de terem sido identificados numerosos factores de prognóstico para o seu sucesso, o aconselhamento e selecção de grávidas para versão cefálica externa deverão ser cautelosos. Os dados obtidos sugerem que a versão cefálica externa deverá continuar a ser oferecida a todas as grávidas elegíveis independentemente de factores prognósticos de sucesso.

Palavras-chave: Apresentação Pélvica; Gravidez; Resultado do Tratamento; Tocólise; Versão Fetal.

\section{INTRODUCTION}

Breech presentation complicates $3 \%$ to $4 \%$ of all pregnancies at term ( $\geq 37$ weeks). ${ }^{1}$ In current obstetrics practice, a breech presentation is associated with a very high likelihood of cesarean delivery $(80-95 \%)^{2,3}$ and strategies have been developed to lower the malpresentation rate at birth.

In external cephalic version (ECV) the pregnant woman is placed in the supine position, with pressure and maneuvers being applied to the maternal abdomen in order to turn the fetus to a cephalic presentation. Through this procedure the rate of noncephalic presentations at term can be reduced, thus lowering the likelihood of non-cephalic births and caesarean sections. ${ }^{4}$ Even though there is not enough evidence from randomized trials to properly assess the complications of ECV, large observational studies suggest that they are rare..$^{4,5}$

Several studies have addressed the prediction of success in ECV6-17 with conflicting evidence. ${ }^{18}$ Multiple

\footnotetext{
1. Departamento/Clínica Universitária de Obstetrícia e Ginecologia. Hospital Universitário de Santa Maria. Centro Hospitalar Lisboa Norte. Lisboa. Portugal.

2. Faculdade de Medicina. Universidade de Lisboa. CAM-Centro Académico de Medicina de Lisboa. Lisboa. Portugal.

$\bowtie$ Autor correspondente: Carolina Vaz de Macedo. cmacedo@campus.ul.pt

Recebido: 10 de Janeiro de 2015 - Aceite: 07 de Maio de 2015 | Copyright @ Ordem dos Médicos 2015
} 
predictive factors have been proposed in these studies, assessed either by clinical history and physical examination or by ultrasound. A meta-analysis conducted in 2008 concluded that the success of an ECV attempt is associated with clinical factors such as multiparity, unengagement of the breech, relaxed uterus, palpable fetal head and a maternal weight inferior to $65 \mathrm{~kg} .{ }^{19}$ The same authors evaluated ultrasound parameters in 2009 , establishing fetal position, amniotic fluid and placental location as factors associated with ECV attempt success. ${ }^{20}$ Modern scoring systems have been developed to forecast success and counsel patients prior to the procedure, but their predictive value is only poor to fair. ${ }^{21-23}$ Therefore, the true implication of previous studies in clinical practice is controversial.

The aim of this study was to identify possible factors that could contribute to the success of an ECV attempt in our population.

\section{MATERIAL AND METHODS}

The study population comprised all women with singleton pregnancies who underwent an ECV attempt from January 1997 to July 2012 in our department. For cases in which a second attempt was performed, we only considered the first one. We excluded from the analysis women in which an ECV attempt was performed with transverse fetal lie, as it was a rare event and also in view of being wellestablished that in such cases an ECV attempt has a much higher likelihood of success than in breech presentation..$^{8,24}$

The maneuver was preferentially conducted between 36 and 38 weeks of gestation. Before the procedure, a nonstress test was conducted and salbutamol was administered for tocolysis $(0.15 \mathrm{mg}$ per hour, doubled every 20 minutes until easily palpable fetal head or maternal heart rate equal or superior to $100 \mathrm{bpm}$ ).

During the procedure, pregnant women were placed in dorsal decubitus, leaning slightly to the left. The operator placed his/her dominant hand on the fetal breech, attempting to disengage it from the maternal pelvis, and pulled it to one side of the maternal abdomen. Simultaneously, the other hand directed the cephalic pole towards the maternal pelvis.

The procedure took place in hospital settings with intermittent fetal auscultation. No analgesia was used. Fetal version was not attempted when there was indication for delivery by cesarean section for any reason, third trimester bleeding, a non-reactive non-stress test, oligohydramnios (amniotic fluid index $\leq 5 \mathrm{~cm}$ ), fetal growth restriction, major fetal malformation, uterine malformation, deflected fetal head or in the presence of a uterine scar, nuchal chord or active labor. The maneuver was interrupted if there was excessive maternal discomfort, fetal bradycardia or after 3 unsuccessful attempts.

We retrospectively analysed all cases by examination of the department's database, which included data on the following variables: race, maternal age, parity, preconceptional maternal body mass index, gestational age, estimated fetal weight, breech category, placental location and amniotic fluid index. The dependent variable was the success/failure of the ECV attempt.

We conducted descriptive and analytical statistics for each variable (qui-square for nominal variables and independent sample t-test for continuous variables). We assessed their possible role as a predictive factor for the success of the ECF attempt by binary logistic regression. We used the software SPSS Statistics $17.0^{\circledR}$ for data registration and statistical analysis. We considered a $p$-value of $<0.05$ as statistically significant. For logistic regression, we used a backward stepwise selection.

\section{RESULTS}

After analysis of the department's database, 217 entries were considered. Of these, 7 were excluded due to being second ECV attempts for a given pregnancy and 3 due to transverse fetal lie. The characteristics of the study population (207 cases) are summarized in the left column of results presented in Table 1.

Our population had a very high percentage of overweight or obese women (77.8\%) and 66.2\% (137/207) of pregnant women who attempted ECV were nulliparous. In $78.2 \%$ $(162 / 207)$ of women the ECV attempt was conducted at 36 or 37 weeks of gestation.

ECV was successful in $46.9 \%$ of cases (97/207). When variables were analysed individually, the only one associated with success was parity (Table 1). Women in whom ECV was concluded with success had a higher parity than the ones in which the procedure failed ( $p=0.007)$.

As placental location is concerned, our first analysis using the four listed categories of the department's database showed no significant differences in the distribution between successful and failed ECV groups. However, a trend appeared towards a higher prevalence of anterior placentas in women in which ECV attempt was not successful (Table 1). We then grouped data regarding placental location into anterior versus other positions. In this analysis we confirmed that an anterior placental location was slightly associated with a lower likelihood of success in a univariate analysis $(p=0.049)$.

When we performed binary logistic regression, none of the variables were a predictor of success for ECV in this study population.

\section{DISCUSSION}

The ECV is a simple and effective procedure that can reduce the cesarean section rate. ${ }^{3}$ Our results show a similar success rate to what has been previously described in literature: in the meta-analysis conducted by Kok in 2008 and 2009 a medium success rate of $53 \%$ and $55 \%$, respectively, is reported. ${ }^{19,20}$

In the first univariate analysis conducted, the only variable associated with the outcome of ECV attempt in our study was parity, with higher parity being linked to a higher chance of success. Other authors have previously described multiparity (defined as parity equal or superior to 2), when compared to nuliparity, as a factor associated with success. ${ }^{16,17}$ 
Table 1 - Characteristics of study population and division according to the outcome of ECV

\begin{tabular}{|c|c|c|c|c|c|}
\hline & Total & Successful ECV & Failed ECV & $\begin{array}{l}\text { Univariate } \\
\text { analysis } \\
\text { ( } p \text {-value) }\end{array}$ & $\begin{array}{l}\text { Binary logistic } \\
\text { regression }\end{array}$ \\
\hline Number of cases & 207 & $97(46.9 \%)$ & $110(53.1 \%)$ & --- & --- \\
\hline \multicolumn{6}{|l|}{ Race } \\
\hline caucasian & $183(88.4 \%)$ & $86(89.6 \%)$ & $97(87.4 \%)$ & NS & NS \\
\hline black & $22(10.6 \%)$ & $9(9.4 \%)$ & $13(11.7 \%)$ & & \\
\hline other & $2(1.0 \%)$ & $1(1.0 \%)$ & $1(0.9 \%)$ & & \\
\hline Maternal age (years) & $29.6 \pm 4.77$ & $30.0 \pm 4.31$ & $29.3 \pm 5.14$ & NS & NS \\
\hline Parity & $0.43 \pm 0.66$ & $0.56 \pm 0.69$ & $0.32 \pm 0.60$ & 0.007 & NS \\
\hline Maternal body mass index $\left(\mathrm{Kg} / \mathrm{m}^{2}\right)$ & $28.0 \pm 3.95$ & $27.55 \pm 3.63$ & $28.39 \pm 4.18$ & NS & NS \\
\hline Gestational age (weeks) & $36.90 \pm 0.89$ & $36.81 \pm 0.89$ & $36.95 \pm 0.90$ & NS & NS \\
\hline Estimated fetal weight (grams) & $2808 \pm 328$ & $2846 \pm 333$ & $2775 \pm 321$ & NS & NS \\
\hline \multicolumn{6}{|l|}{ Breech category } \\
\hline frank & $176(85.0 \%)$ & $84(87.5 \%)$ & $92(82.9 \%)$ & NS & NS \\
\hline complete & $19(9.2 \%)$ & $7(7.3 \%)$ & $12(10.8 \%)$ & & \\
\hline footling & $12(5.8 \%)$ & $5(5.2 \%)$ & $7(6.3 \%)$ & & \\
\hline \multicolumn{6}{|l|}{ Placental location } \\
\hline anterior & $75(36.2 \%)$ & $28(29.2 \%)$ & $47(42.3 \%)$ & $\mathrm{NS}^{*}$ & NS \\
\hline posterior & $85(41.1 \%)$ & $45(46.9 \%)$ & $40(36.0 \%)$ & & \\
\hline fundal & $28(13.5 \%)$ & $14(14.6 \%)$ & $14(12.6 \%)$ & & \\
\hline lateral & $19(9.2 \%)$ & $9(9.4 \%)$ & $10(9.0 \%)$ & & \\
\hline Amniotic fluid index $(\mathrm{cm})$ & $12.54 \pm 3.61$ & $13.07 \pm 3.65$ & $11.98 \pm 3.53$ & NS & NS \\
\hline
\end{tabular}

Values are given as mean \pm standard deviation or absolute number (percentage). NS: Not significant. * Refers to the 2-sided qui-square test when the four locations were considered. After grouping for anterior versus others, a significant difference was found $(p=0.049)$.

We then decided to group placental location into anterior versus other positions as other authors previously proposed this division as being the most appropriate for determining success of an ECV attempt. ${ }^{14,20}$ After doing so, an anterior placenta emerges as a negative predictive factor for the outcome of the procedure.

However, the variables mentioned could not be considered independent from one another and there was need to adjust for confounding factors. When analyzed by binary logistic regression, none of the variables were associated with success of ECV attempts.

As already mentioned, despite of all factors reported to be associated with outcome for ECV attempts, evidence for the impact of each is conflicting. ${ }^{18}$ Moreover, new predictive factors such as myometrial thickness have been recently reported. ${ }^{25} \mathrm{~A}$ review in Portuguese for complications and factors associated with the success rate of the procedure was recently published by Camões. ${ }^{26}$

In our department, all ECV attempts were performed using tocolysis with salbutamol. According to the Cochrane Database of Systematic Reviews, the use of betamimetics to facilitate ECV is associated with an increase in cephalic presentation in labor and birth. ${ }^{27} \mathrm{~A}$ decrease in cesarean section rate in both nulliparous and multiparous women 
was reported. ${ }^{27}$ In particular, salbutamol is effective as an adjunct for $E C V .{ }^{28}$ There is, however, insufficient evidence regarding adverse effects and comparison between routine and selective use of tocolysis. ${ }^{27}$

In this study, we attempted to exclude biases by analyzing results using a binary logistic regression, which clearly contributed to the lack of association. We highlight that care must be taken when assuming a determined factor is associated with the outcome of the procedure, as there are multiple confounding variables that may not be accounted for.

The analysis of our results is limited by a relatively small sample, even though other authors have found associations using a smaller sample. ${ }^{17}$ Moreover, the retrospective nature of this work limits the interpretation of results. The variables chosen to be included in this study were also limited by the data available in our database and others could be equally important to analyse.

\section{CONCLUSIONS}

Authors who have proposed the use of predictive scores suggested that these may be useful in counselling and selecting patients for ECV attempt. ${ }^{21-23}$ On the other hand, despite of the lack of evidence regarding physicians' attitudes towards ECV, occasional reports suggest that most eligible women are not being offered the possibility of undergoing this procedure. ${ }^{29-31}$

\section{REFERENCES}

1. Hickok DE, Gordon DC, Milberg JA, Williams MA, Daling JR. The frequency of breech presentation by gestational age at birth: a large population-based study. Am J Obstet Gynecol. 1992;166:851-2.

2. Rietberg CC, Elferink-Stinkens PM, Visser GH. The effect of the Term Breech Trial on medical intervention behaviour and neonatal outcome in the Netherlands: an analysis of 35,453 term breech infants. BJOG. 2005;112:205-9.

3. Gilbert W, Hicks SM, Boe NM, Danielsen B. Vaginal versus caesarean delivery for breech presentation in California: a population-based study. Obstet Gynecol. 2003;102:911-17.

4. Hofmeyr GJ, Kulier R, West HM. External cephalic version for breech presentation at term. Cochrane Database Syst Rev. 2015;4:CD000083.

5. Grootsholten K, Kok M, Oei SG. External cephalic version-related risks: a meta-analysis. Obstet Gynecol. 2008;112:1143-51.

6. Ferguson JE, Armstrong MA, Dyson DC. Maternal and fetal factors affecting success of antepartum external cephalic version. Obstet Gynecol. 1987;70:722-5.

7. Fortunato SJ, Mercer LJ, Guzick DS. External cephalic version with tocolysis: factors associated with success. Obstet Gynecol. 1988:72:59-62.

8. Donald WL, Barton JJ. Ultrasonography and external cephalic version at term. Am J Obstet Gynecol. 1990;162:1542-5.

9. Newman RB, Peacock BS, VanDorsten JP, Hunt HH. Predicting success of external cephalic version. Am J Obstet Gynecol. 1993;169:245-9.

10. Foote AJ. External cephalic version from 34 weeks under tocolysis: factors influencing success. J Obstet Gynaecol. 1995;21:127-32.

11. Aisenbrey GA, Catanzarite VA, Nelson C. External cephalic version: predictors of success. Obstet Gynecol. 1999;94:783-6.

12. Guyer H. A prospective audit of external cephalic version at term: are ultrasound parameters predictive of outcome? J Obstet Gynaecol. 2001;21:580-2.

13. Boucher M, Bujold E, Marquette GP, Vezina Y. The relationship between amniotic fluid index and successful external cephalic version: a 14-year experience. Am J Obstet Gynecol. 2003;189:751-4.

14. Ben-Meir A, Erez Y, Sela HY, Shveiky D, Tsafrir A, Ezra Y. Prognostic parameters for successful external cephalic version. J Matern Fetal
In our opinion, the definition of factors associated with a lower likelihood of success might contribute to a suboptimal offering of ECV attempts. As this study shows, it is still unclear that classically described factors have that much of an impact on how successful the procedure would be. Consequently, in view of our results and of the low performance of the previously described predictive scores, we believe ECV should continue being offered to all eligible patients regardless of the presence or absence of prognostic factors for success.

\section{PROTECTION OF HUMANS AND ANIMALS}

The authors declare that the procedures were followed according to the regulations established by the Clinical Research and Ethics Committee and to the Helsinki Declaration of the World Medical Association.

\section{DATA CONFIDENTIALITY}

The authors declare having followed the protocols in use at their working center regarding patient's data publication.

\section{CONFLICTS OF INTEREST}

The authors declare that there are no conflicts of interest.

\section{FUNDING SOURCES}

No subsidies or grants contributed to this work.

Neonatal Med. 2008;21:660-2.

15. Burgos J, Melchor JC, Cobos P, Centeno M, Pijoan Jl, FernandezLlebrez $\mathrm{L}$, et al. Does fetal weight estimated by ultrasound really affect the success rate of external cephalic version? Acta Obstet Gynecol Scand. 2009;88:1101-6.

16. Burgos J, Melchor JC, Pijoán Jl, Cobos P, Fernández-Llebrez L, Martínez-Astorquiza T. A prospective study of the factors associated with the success rate of external cephalic version for breech presentation at term. Int J Gynaecol Obstet. 2011;112:48-51.

17. Obeidat N, Lataifeh I, Al-Khateeb M, Zayed F, Khriesat W, Amarin Z. Factors associated with the success of external cephalic version (ECV) of breech presentation at term. Clin Exp Obstet Gynecol. 2011;38:3869 .

18. American College of Obstetricians and Gynecologists. ACOG practice bulletin: external cephalic version - Clinical Management Guidelines for Obstetrician-Gynecologists Number 13. Int J Gynaecol Obstet. 2001;72:198-204

19. Kok M, Cnossen J, Gravendeel L, Van Der Post J, Opmeer B, Mol BW. Clinical factors to predict the outcome of external cephalic version: a meta-analysis. Am J Obstet Gynecol. 2008;199:630.e1-7.

20. Kok M, Cnossen J, Gravendeel L, Van Der Post JA, Mol BW. Ultrasound factors to predict the outcome of external cephalic version: a metaanalysis. Ultrasound Obstet Gynecol. 2009;33:76-84.

21. Kok M, Van Der Steeg JW, Van Der Post JA, Mol BW. Prediction of success of external cephalic version after 36 weeks. Am J Perinatol. 2011;28:103-10

22. Burgos J, Cobos $\mathrm{P}$, Rodriguez L, Pijoán JI, Fernández-Llebrez L, Martínez-Astorquiza T, et al. Clinical score for the outcome of external cephalic version: a two-phase prospective study. Aust N Z J Obstet Gynaecol. 2012;52:59-61.

23. De Hundt M, Vlemmix F, Kok M, Van Der Steeg JW, Bais JM, Mol BW, et al. External validation of a prediction model for successful external cephalic version. Am J Perinatol. 2012;29:231-6.

24. Hellstrom AC, Nilsson B, Stange L, Nylund L. When does external cephalic version succeed? Acta Obstet Gynecol Scand. 1990;69:281- 
25. Buhtmscht CS, Buhtmscht IA, Wehrum MJ, Molaskey-Jones S, Sfakianaki AK, Pettker CM, et al. Ultrasonographic evaluation of myometrial thickness and prediction of a successful external cephalic version. Obstet Gynecol. 2011;118:913-20.

26. Camões S, Ayres-de-Campos D. Versão cefálica externa: uma revisão das complicações e da taxa de sucesso. Acta Obstet Ginecol Port. 2013;7:29-35

27. Cluver C, Gyte GM, Sinclair M, Dowswell T, Hofmeyr GJ. Interventions for helping to turn term breech babies to head first presentation when using external cephalic version. Cochrane Database Syst Rev. 2015;2:CD000184.
28. Vani S, Lau SY, Lim BK, Omar SZ, Tan PC. Intravenous salbutamol for external cephalic version. Int J Gynaecol Obstet. 2009;104:28-31.

29. Caukwell S, Joels LA, Kyle PM, Mills MS. Women's attitudes towards management of breech presentation at term. J Obstet Gynaecol. 2002;22:486-8.

30. Rijnders $M$, Offerhaus $P$, van Dommelen $P$, Wiegers $T$, Buitendijk $S$. Prevalence, outcome, and women's experiences of external cephalic version in a low-risk population. Birth. 2010;37:124-33

31. Shaaban MM, Ahmed WS, Khadr Z, El-Sayed HF. Obstetricians' perspective towards cesarean section delivery based on professional level: experience from Egypt. Arch Gynecol Obstet. 2012;286:317-23. 


\section{Prediction of Success in External Cephalic Version under Tocolysis: Still a Challenge}

Acta Med Port 2015:28:554-558

Publicado pela Acta Médica Portuguesa, a Revista Científica da Ordem dos Médicos

Av. Almirante Gago Coutinho, 151

1749-084 Lisboa, Portugal.

Tel: +351218428 215

E-mail: submissao@actamedicaportuguesa.com

www.actamedicaportuguesa.com

ISSN:0870-399X | e-ISSN: 1646-0758

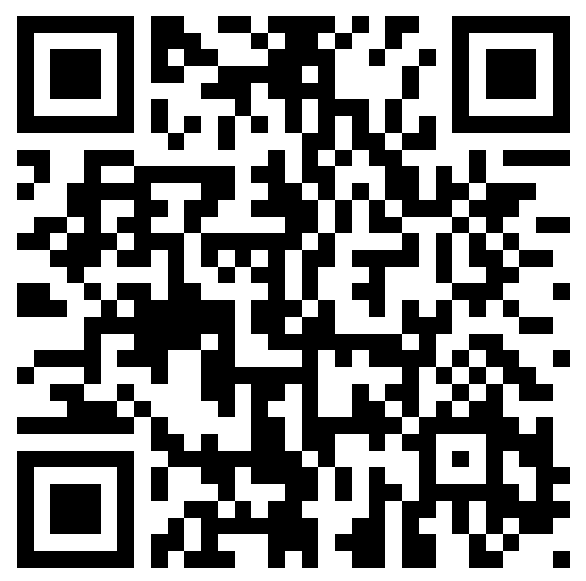

